\title{
〔原著論文〕
}

\section{示差走査熱量曲線のピーク分離によるポリエチレン/ポリスチレンブロック 共重合体の等温結晶化挙動の解明}

\author{
擋上 将規 $* 1 \cdot$ 関谷 美穂 $* 2 \cdot$ 東宮 大貴 $* 2$ \\ 山延 健*2 $・$ 上原 宏樹*2
}

(受付 2018 年 9 月 6 日・審査終了 2018 年 11 月 5 日)

(早期公開 2018 年 12 月 18 日 - DOI:10.1295/koron.2018-0047)

\begin{abstract}
要 旨 本研究では, 異なる結晶化温度 $\left(T_{\mathrm{c}}\right)$ で等温結晶 化させたポリエチレン/ポリスチレンブロック共重合体 (PE$b$-PS) の示差走査熱量 (DSC) 測定における融解挙動をピーク 分離法を用いて解析することで，その結晶化挙動を調查し た。等温結晶化試料に対してDSC 測定を行ったところ， $T_{\mathrm{c}}$ にほとんど依存しない高温融解ピークと $T_{\mathrm{c}}$ に依存する低温 融解ピークが観察された，前者は溶融状態から $T_{\mathrm{c}}$ までの急 冷過程で結晶化した分岐成分をほとんど含まない結晶の融 解，後者は等温結晶化過程で結晶化した分岐成分を含む結 晶の融解に由来すると考えられる，さらに，より低温側に $T_{\mathrm{c}}$ に依存するブロードな融解ピークも観察され，これは等 温結晶化後の急冷過程で結晶化したPS 界面近傍の結晶の融 解によるものと考元られる。このように DSC 融解曲線の ピーク分離により融解挙動を解析することで, 結晶相に扔 けるドメイン形成を予想することができた。
\end{abstract}

\section{1 緒訔}

近年，多くの材料についてナノスケールでの構造形成 挙動が注目されている。 とくに，高分子をナノ空間内で 結晶化させると，鎖状の分子形態を反映して分子運動に 大きな制限を受けるため, 特異な結晶化挙動が進行する ことが明らかとなっている。たとえば，Shin (1),2)はア ルミナナノ細孔内に充填したポリエチレン $(\mathrm{PE})$ の結晶 化温度がバルクのそれよりも顕著に低いことを報告して いる。また，このような制限空間ではステレオコンプ レックス型ポリ乳酸への特異的な結晶化が促進するこ とも報告されている3). 同様に，ナノメートルレベルで の相分離構造を形成するブロック共重合体では，各セグ メントの相構造形成が空間的な制限を受ける。よって,

*1 信州大学先鋭領域融合研究群国際ファイバー工学研究所 (画386-8567 上田市常田3-15-1)

*2 群馬大学大学院理工学府分子科学部門 (函376-8515 桐生 市天神町 1-5-1)

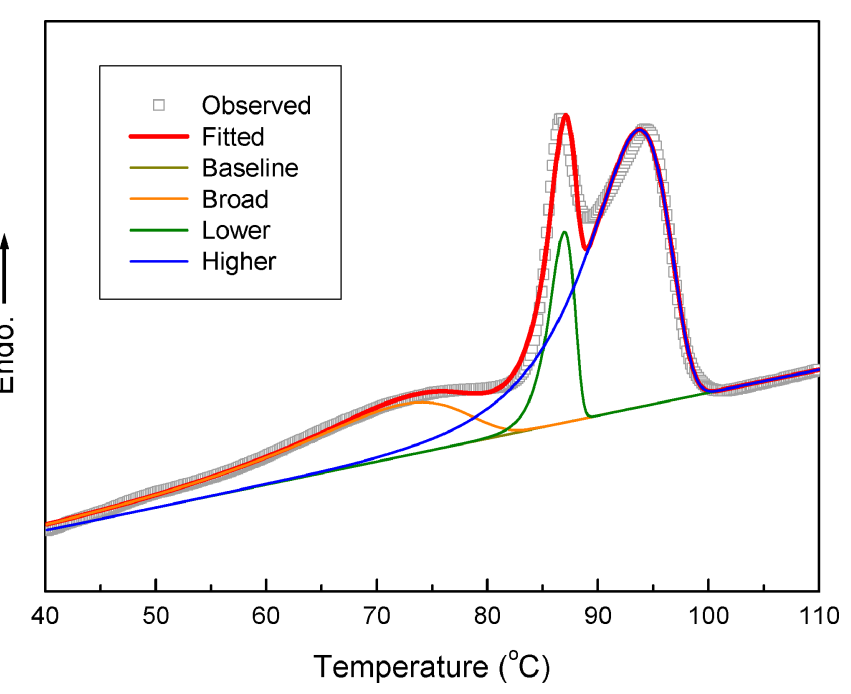

片方あるいは両方のセグメントが結晶性である場合, 拘束下での結晶化が進行していることになり，そのよ うな非平衡状態での相構造形成メカニズムが注目されて (る4) 12). Müller ${ }^{13), 14) ~ は ， ホ ゚ リ エ チ レ ン / ホ ゚ リ ス チ レ ~}$ ンブロック共重合体 (PE- $b$-PS) に対して核形成とアニー リングを繰返す successive self-nucleation/annealing (SSA) 処理を施すことで同じ試料内にさまざまな温度でア ニーリングされた結晶を形成し，その融解挙動からラメ ラ厚分布を求め, ドメイン内でのラメラ・パッキングの 様子を推測している. Nojima ら 15) 17) は, 小角 X線散 乱 (SAXS) 測定を用いて結晶性/結晶性ジブロック共重合 体における結晶ドメイン形成挙動を調査している。

筆者ら ${ }^{18) \sim 24)}$ はこれまで結晶性/非晶性ジブロック共 重合体である PE- $b$-PS フィルムの等温結晶化条件を制御 することでそのミクロ相分離構造 (共連続構造)を制御し てきた，さらに，膨潤延伸による構造配列 ${ }^{18), 24) ， フ ゙ レ ~}$ ンドによるミクロ相分離構造の複合化 ${ }^{22), 23)}$ ，あるいは 非晶成分の発煙硝酸エッチングよる多孔化 ${ }^{19), 20), 22), 23) ~ を ~}$ 
利用した生体膜 ${ }^{20), 23)}$ ，PS 成分のスルホン化による電解 質膜 ${ }^{21)}$ へ応用を検討してきた。このPE- $b$-PS 等温結晶 化フィルムの融解挙動を示差走査熱量計 (DSC) により測 定すると, 同一温度でいくら長時間アニーリングや結晶 化しても多重融解ピークが現れてしまう22)。これは, PE (結晶) 相内に形成過程の異なる複数の結晶ドメイン を有していることを示唆している。このような現象につ いては，ポリブタジエン $(\mathrm{PB})$ の水素添加によって得ら れる直鎖状低密度ポリエチレン (LLDPE) においても同

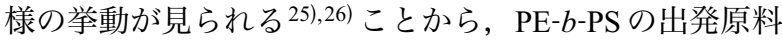
である PB/PS ジブロック共重合体 (PB- $b$-PS) の PB の 1,2付加に由来するエチル分岐による可能性が示唆されて いる ${ }^{8), 22)}$. 分岐成分は結晶セグメント内にありながら 結晶化できないため, 多くの場合非晶成分として振舞 うことになる。一方で，この1,2-付加によるエチル分岐 成分は結晶相内に取り込まれていることが，エッチング によって非晶相を除去した PE- $b$-PS フィルムの ${ }^{1} \mathrm{H}$ 核磁 気共鳴 (NMR) 測定から示唆されている22). しかしなが ら，このような分岐成分の存在が PE- $b$-PS の結晶化にど のような影響を与えているかについてはこれまで詳細に 検討されていない.

ここで，複数のピークを含む結晶性高分子の DSC 融 解曲線については, ピーク分離法による融解挙動の詳細 な解析が行われている。たとえば，溶融超延伸PEフィ ルムにおける異なる融点をもつ結晶構造 (シシカバブ構 造) の評価 ${ }^{27)}$, あるいは $\beta$ 晶結晶化アイソタクチックポ リプロピレン (i-PP) の融解および $\alpha$ 晶への再結晶挙動の 解析 ${ }^{28)}$,29) がある。この手法では，単一組成からなる結 晶相における複数の結晶成分を詳細に調査することがで きる。そこで本研究では，異なる結晶化温度で等温結晶 化させた PE- $b$-PS 試料の DSC 融解挙動をピーク分離法 を用いて解析することにより，その構造形成メカニズム を調査した。

\section{2 実験}

\section{1 試料}

試料として PE- $b$-PS (Polymer Source 社製) を用いた. PE成分およびPS成分の数平均分子量はそれぞれ $67 \mathrm{k}$ お

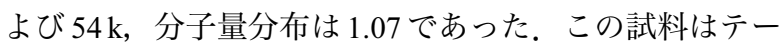
パードブロックコポリマーであり，テーパー部分がモ ノマー 20 個程度のランダム結合である。また，この試料 はPB- $b$-PS の水素添加により得られたものであり，その 1,4-付加の割合は $90 \%$ 以上である。なお，この PE- $b$-PS の等温結晶化フィルムは共連続構造を形成する ${ }^{18) ~ 24) . ~}$

\section{2 等温結晶化試料の作製}

PE- $b$-PS 試料に $1 \mathrm{wt} \%$ になるように $p$-キシレンを加 え，沸点で溶かし込みを行った。この溶液をキャスト 後, 室温で乾燥させキャストフィルム (厚さ約 $50 \mu \mathrm{m})$ を
得た。等温結晶化試料の作製は Perkin-Elmer 社製 Pyris 1 DSC を用いて窒素流通下，DSC 炉内で行った。得られ たキャストフィルムをアルミパンに約 $1 \mathrm{mg}$ 詰め, DSC 炉内において $180^{\circ} \mathrm{C} て ゙ 10$ 分間保持して溶融した後, $50 \sim 100^{\circ} \mathrm{C}$ の等温結晶化温度 $\left(T_{\mathrm{c}}\right)$ まで急冷，その温度で 12 時間保持後, $30^{\circ} \mathrm{C}$ まで急冷することで等温結晶化試 料を得た。

\section{3 測定}

等温結晶化試料の DSC 融解曲線の測定は Perkin-Elmer 社製 Pyris 1 DSC を用いて窒素流通下， $30^{\circ} \mathrm{C}$ から $180^{\circ} \mathrm{C}$ まで昇温速度 $10^{\circ} \mathrm{C} / \mathrm{min}$ で行った。このとき，インジウ ムとスズを用いて温度および熱量の補正を行った。PE 成分の結晶化度は, PE 完全結晶の融解熱 $\left(\Delta H_{\mathrm{m}}{ }^{0}\right)$ を $290 \mathrm{~J} / \mathrm{g}^{30)}$ として DSC 融解ピーク面積 [融解熱 $\left.\left(\Delta H_{\mathrm{m}}\right)\right]$ か ら算出した。

\section{3 結果と考察}

Figure 1 にキャストフィルムを昇温 (1st heating run), $180^{\circ} \mathrm{C}$ で溶融後, $10^{\circ} \mathrm{C} / \mathrm{min}$ で $30^{\circ} \mathrm{C}$ まで冷却 (cooling run) し再昇温 (2nd heating run) した時の DSC 曲線を示す。冷 却曲線は $80^{\circ} \mathrm{C}$ 付近にピークを有していることから， 通常の冷却結晶化をさせた場合の結晶化温度は $80^{\circ} \mathrm{C}$ 程 度になると予想される。また，融解ピークは 1 st heating run, 2nd heating runともに単一ピークであった。

次に，50〜 $100^{\circ} \mathrm{C}$ の各 $T_{\mathrm{c}}$ で等温結晶化させた試料の DSC 融解曲線を比較した. Figure 2 に各 $T_{\mathrm{c}}$ で得られた等 温結晶化試料の DSC 融解曲線を示す。 $50 \sim 85^{\circ} \mathrm{C}$ の $T_{\mathrm{c}}$ に おいてメインピークが二重融解ピークとなっていること がわかる，ここで，PEホモポリマーは結晶化温度が高 く，また結晶化速度が速いため，等温結晶化を経てもそ の融解曲線はほぼ急冷過程での結晶化に由来する結晶の 融解ピークとなる ${ }^{31), 32)}$ 。一方，水素添加によって得ら

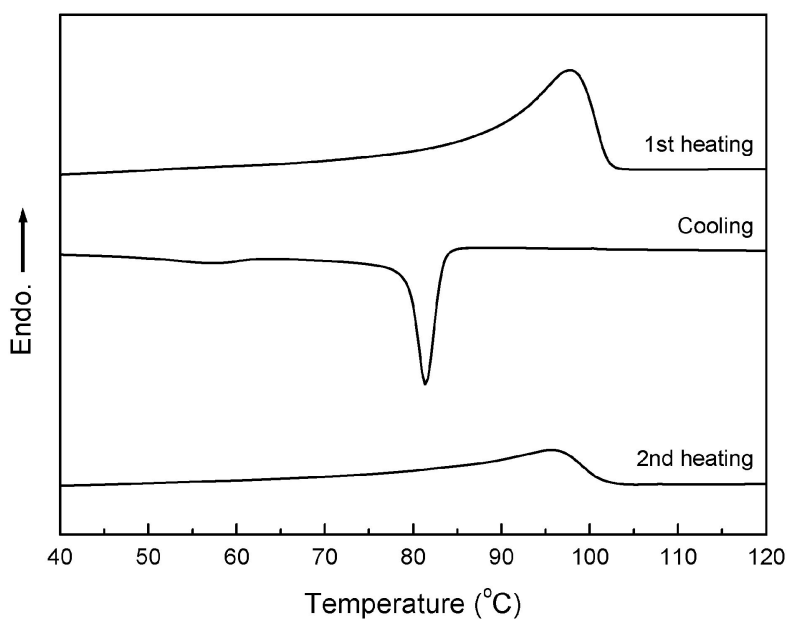

Figure 1. DSC thermograms (1st heating, cooling, and 2nd heating) for a cast film. 


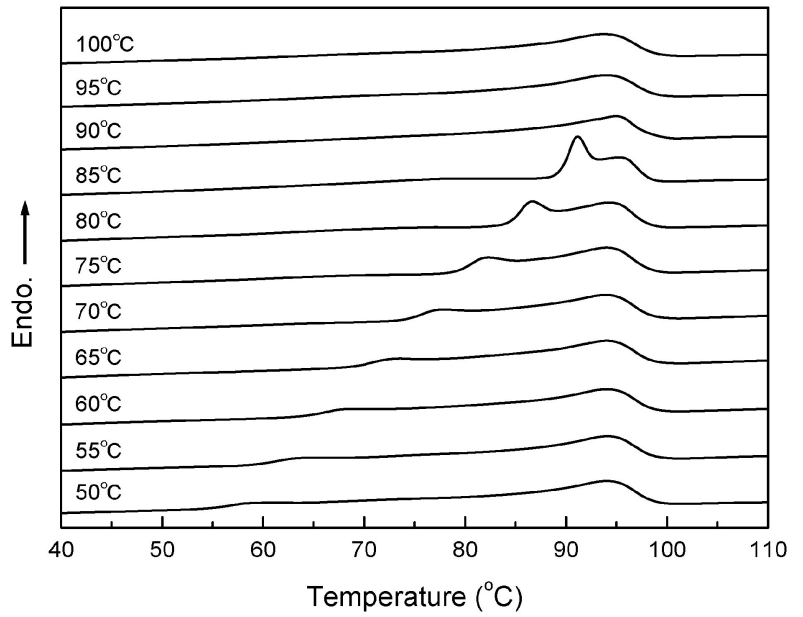

Figure 2. DSC melting thermograms for isothermally crystallized samples prepared at different $T_{\mathrm{c}}$ 's.

れた PE- $b$-PS およびPEの等温結晶化試料では明確な多 重融解ピークが観察される5),8)ことから，この等温結晶 化試料での多重融解ピークの出現は分岐の存在によるも のと考えられる。ささらに，その融解挙動はPE- $b$-PS と $\mathrm{PE}$ で異なる5)ことから，ブロック共重合体に由来する 挙動が含まれていると言える。観察された二重融解 ピークのうち，高温側ピークの位置は $T_{\mathrm{c}}$ にほとんど依 存せず，約 $94^{\circ} \mathrm{C}$ の一定值を示していた。これは冷却結 晶化試料の融解ピーク (Figure 1, 2nd heating run) とも類 似していることから， $T_{\mathrm{c}}$ に至る前の急冷過程で結晶化し た結晶に由来する融解ピークと考えられる。一方，低温 側のピークは $T_{\mathrm{c}}$ が高くなるにつれて高温側へシフトし ていく様子が観察された。 よって，この低温側ピークは 等温結晶化過程で結晶化した結晶に由来する融解ピーク と考えられる. $T_{\mathrm{c}}=90^{\circ} \mathrm{C}$ で等温結晶化させた試料では, 単一融解ピーク $\left(\right.$ 約 $\left.95^{\circ} \mathrm{C}\right)$ が観察された。一方で, $T_{\mathrm{c}}>$ $90^{\circ} \mathrm{C}$ では単一融解ピークが観察されたものの, ピーク はブロードになりそのピーク温度はやや低温側にシフト していた。これは， $T_{\mathrm{c}}$ での結晶化が十分に進行しな かったことを示唆している。これらの $T_{\mathrm{c}}$ は結晶化温度 (Figure 1, cooling run)よりも高く, さらにPSのガラス 転移温度 $\left(T_{\mathrm{g}}\right.$, 約 $\left.100^{\circ} \mathrm{C}\right)$ に近く系全体の分子運動性が増 加したため, 溶融アニール状態となり $T_{\mathrm{c}}$ での結晶化が 十分に進行しなかったと考えられる.さらに， $T_{\mathrm{c}}=$ $70 \sim 85^{\circ} \mathrm{C}$ では低温側ピークよりもさらに低温側に非常 にブロードな融解ピークが観察された。なお，これらの 多重融解ピークについて昇温速度依存性は認められな かった.

そこで，これら高温側ピーク，低温側ピーク，および ブロードピークの挙動を詳しく解析するために, $T_{\mathrm{c}}=$ $70 \sim 90^{\circ} \mathrm{C}$ の等温結晶化試料の DSC 融解曲線で観察され た多重融解ピークに対してピーク分離を行った。 ピーク
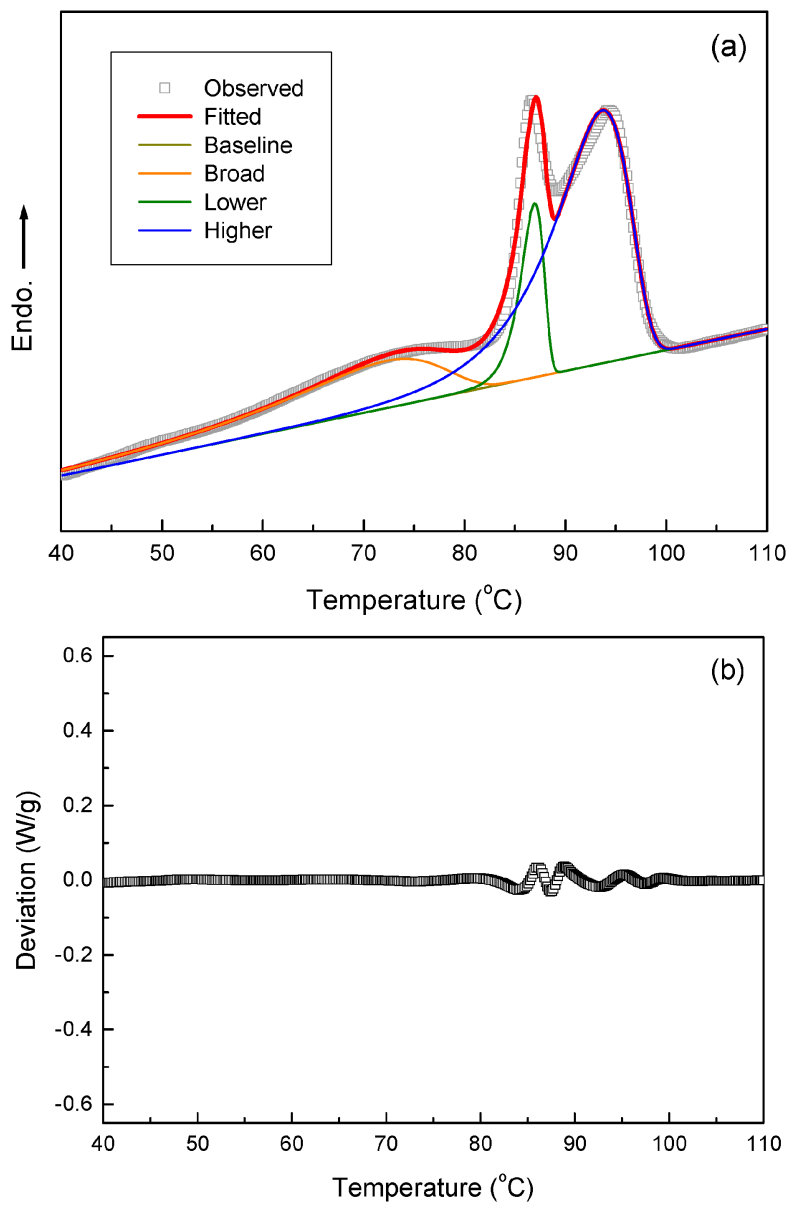

Figure 3. (Color online) (a) A typical result of peak fitting for a DSC melting thermogram $\left(T_{\mathrm{c}}=80^{\circ} \mathrm{C}\right)$ resolved into broad (yellow line), lower (green line), and higher melting peaks (blue line). The grey dots indicate the observed data. The red line indicates the resultant fitted curve including these melting peaks. (b) The deviation of the fitting value from the experimental value.

分離にはポリオレフィンの DSC 多重融解ピークの分離 に用いられる Extreme 関数を用いた ${ }^{27,28)}$. ピーク分離の 一例を Figure 3 に示す. Figure 3(b) の誤差曲線を見て も，実測值とピークフィッティング曲線がよく一致して いることがわかる. Figure 4 に各 $T_{\mathrm{c}}$ の DSC 融解曲線を ピーク分離することで得られた高温ピーク，低温ピー ク，およびブロードピークを比較したものをそれぞれ示 す。また，これらの分離ピークから見積もったピーク トップ温度 $\left(T_{\mathrm{m}}\right)$, ピーク面積 [融解熱 $\left(\Delta H_{\mathrm{m}}\right)$ ], および ピーク面積割合の $T_{\mathrm{c}}$ に対する変化を Figure 5, Figure 6, およびFigure 7 に示す。まず高温ピークを見ると， $T_{\mathrm{m}}$ は $T_{\mathrm{c}}$ の上昇とともにわずかに高温側へシフトするもののほ とんど変化せず， $T_{\mathrm{c}}$ に依存していないことがわかる. PE- $b$-PS の PE 分子鎖は PS 相の影響を強く受けると予想 されることから，この結晶成分は溶融状態からの急冷過 程において PSの $T_{\mathrm{g}}$ 以下となった際に $\mathrm{PE}$ 分子鎖の運動性 が低下することで結晶化した結晶と考えられる。これ 

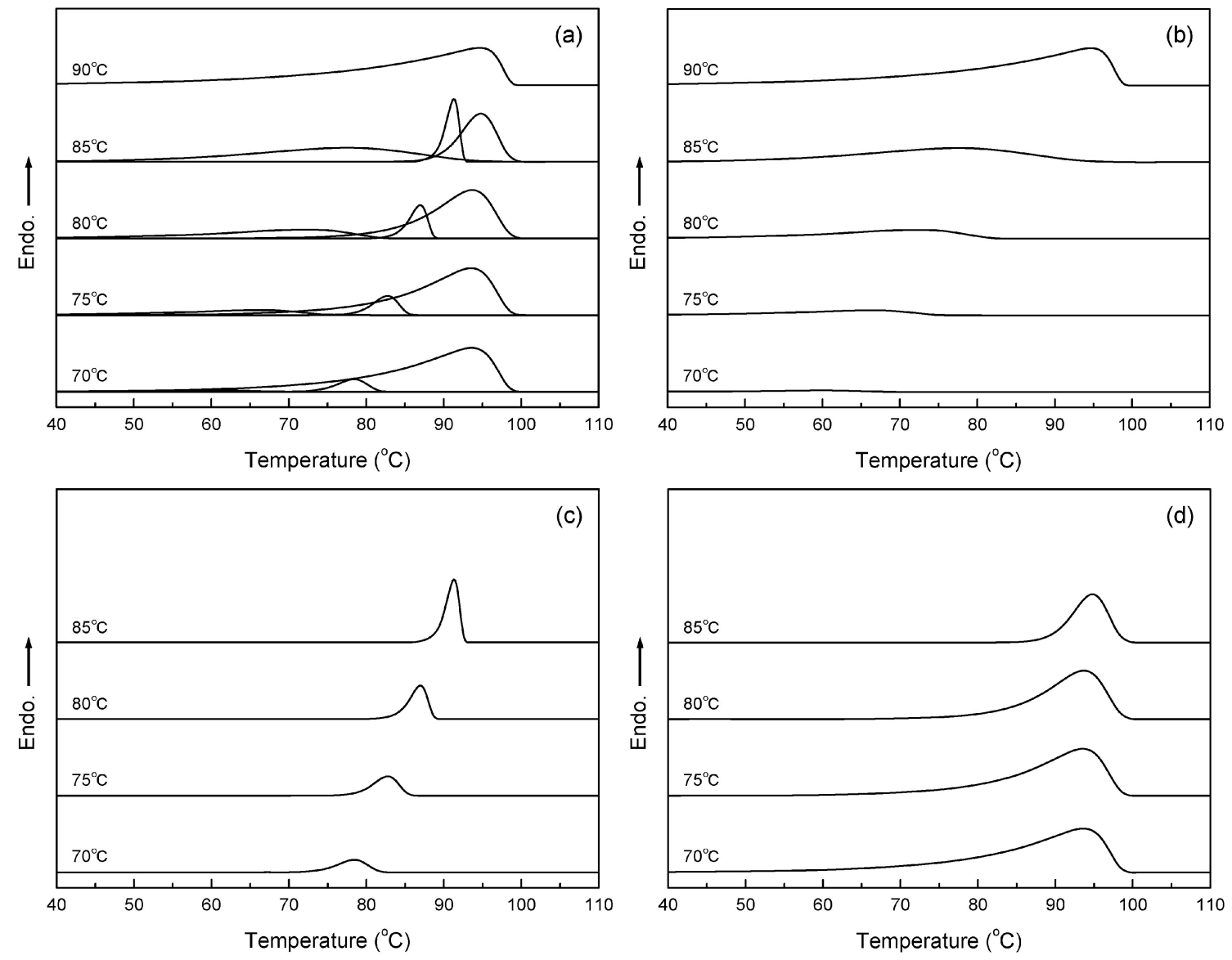

Figure 4. Changes in peak-separated DSC curves: (a) overwriting, (b) broad, (c) lower, and (d) higher melting peaks.

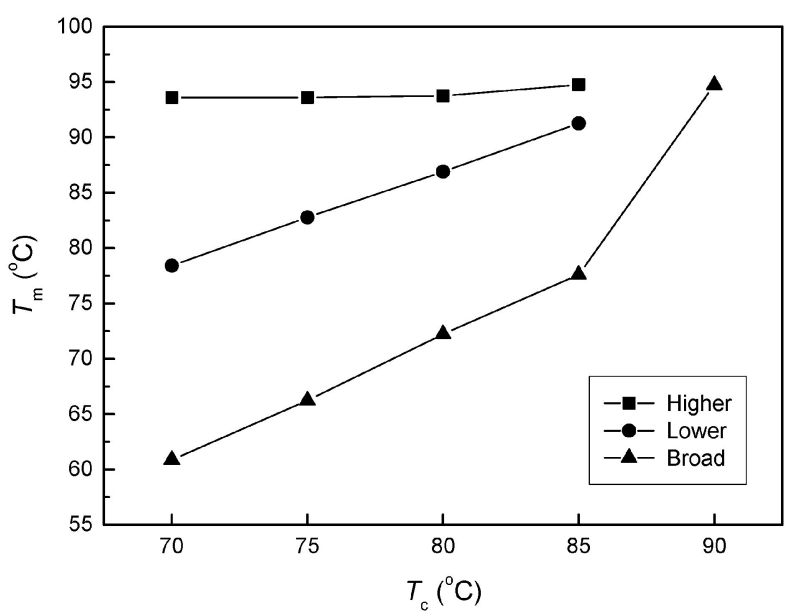

Figure 5. Relationships between peak top temperature $\left(T_{\mathrm{m}}\right)$ and $T_{\mathrm{c}}$ for each separated melting peak.

は, $80^{\circ} \mathrm{C}$ 付近の冷却結晶化ピーク (Figure 1) に対応して いる．急冷過程で結晶化できるのは結晶化速度の速い成 分であることから，この結晶成分は分岐成分をほとんど 含まない結晶と考えられる， $T_{\mathrm{c}}$ が低くなるとこの急冷
過程での結晶化がより低温まで進行するため, その融解 ピークは低温側に裾を引くようになる，次に低温ピーク を見ると， $T_{\mathrm{c}}$ の上昇とともに $T_{\mathrm{m}}$ が直線的に上昇し，ま たそのピーク面積はわずかに増加していた。このことか ら，この結晶成分は等温結晶化過程で結晶化した結晶 と考えられる。この成分は, 高温ピークを与える結晶成 分に比べて結晶化速度が遅いことから，分岐を含む成分 であると予想される。この結晶化は，55-60 ${ }^{\circ} \mathrm{C}$ 見られ る微小な冷却結晶化ピーク (Figure 1)に対応していると 考えられる. なお, この低温ピークの $T_{\mathrm{m}}$ は $T_{\mathrm{m}}=T_{\mathrm{c}}$ の直 線とほぼ平行に推移しており (Figure 5), これは一般的 なHoffman-Weeks プロットに見られる挙動とは異なる。 このような挙動は水素添加によって得られた PE- $b-$ $\mathrm{PS}^{5), 8), 22)}$ あるいはPBの水素添加により得られたコポリ マー33)にも観察されることから, ブロック共重合体に由 来するものではなく，分岐の存在によるものと考えられ る。これは，このような分岐を含む PEでは融解範囲が 広く, $T_{\mathrm{c}}$ と重なるためと推測される ${ }^{8)}$.

最も低温側に現れるブロードピークも低温ピークと同 じく $T_{\mathrm{c}}$ の上昇とともに $T_{\mathrm{m}}$ が直線的に上昇するものの, $T_{\mathrm{c}} \leq 85^{\circ} \mathrm{C}$ では $T_{\mathrm{c}}$ よりも低い $T_{\mathrm{m}}$ を示していた. よってこ 


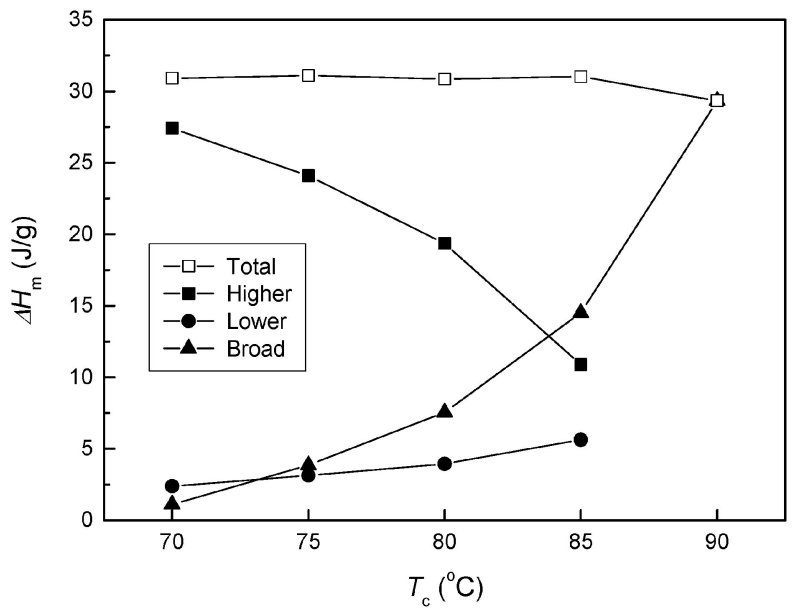

Figure 6. Relationships between peak area (heat of fusion; $\Delta H_{\mathrm{m}}$ ) and $T_{\mathrm{c}}$ for each separated melting peak.

のピークは等温結晶化過程で結晶化した結晶によるもの ではなく, 等温結晶化後の急冷過程で結晶化した結晶に よるものと考えられる。そのため, 低温側のブロード ピークは見かけ上 $T_{\mathrm{c}}$ に依存して変化する。急冷過程で の結晶化であることから，このブロードピークを与える 結晶成分は高温ピークと同じく結晶化速度の速い分岐成 分をほとんぞ含まない結晶と考えられる。しかしなが ら, 等温結晶化前の急冷過程では結晶化しないことか ら，こ扎は分子鎖運動性の低い，ょり PE-PS 界面に近い $\mathrm{PE}$ 分子鎖からなる結晶と考元られる。逆に言えば，高 温ピークは界面の影響を受けにくい分子末端に近い $\mathrm{PE}$ 分子鎖からなる結晶の融解によるものと予想される。こ こで, ブロードピークの $\Delta H_{\mathrm{m}}$ は $T_{\mathrm{c}}$ の増加とともに増加 するものの, 高温ピークとブロードピークの $\Delta H_{\mathrm{m}}$ の和 は $T_{\mathrm{c}}$ によってほとんど変化しない (Figure 6). このこと から, 急冷過程で結晶化することができる分岐の少ない $\mathrm{PE}$ 分子鎖の領域は $T_{\mathrm{c}}$ にっって変化せず，溶融状態から $T_{\mathrm{c}}$ への急冷過程と等温結晶化後の急冷過程で結晶化する

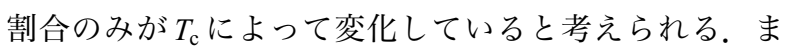
た, 結晶化できるPE成分のほとんどが急冷過程で結晶 化する結晶化速度の速い成分 (高温ピーク+ブロード ピーク)であることから (Figure 7), 試料の結晶化度は $T_{\mathrm{c}}$ によってほとんど変化しない (Figure 6).PE成分の結晶 化度は約 19\%であり, これは報告されている水素添加 によって得られた PE- $b$-PS あるいはPE の值 ${ }^{5}$ と同程度 である。このことから，分岐成分をもつ $\mathrm{PE}$ 分子鎖の大 部分は結晶化できず，非晶相に濃縮されていると考元ら れる。

これらの結果より, PE- $b$-PS 等温結晶化試料の共連続 構造における結晶相は結晶化挙動の異なる以下の三つの ドメインからなると予想される：(i) 溶融状態から $T_{\mathrm{c}}$ ま

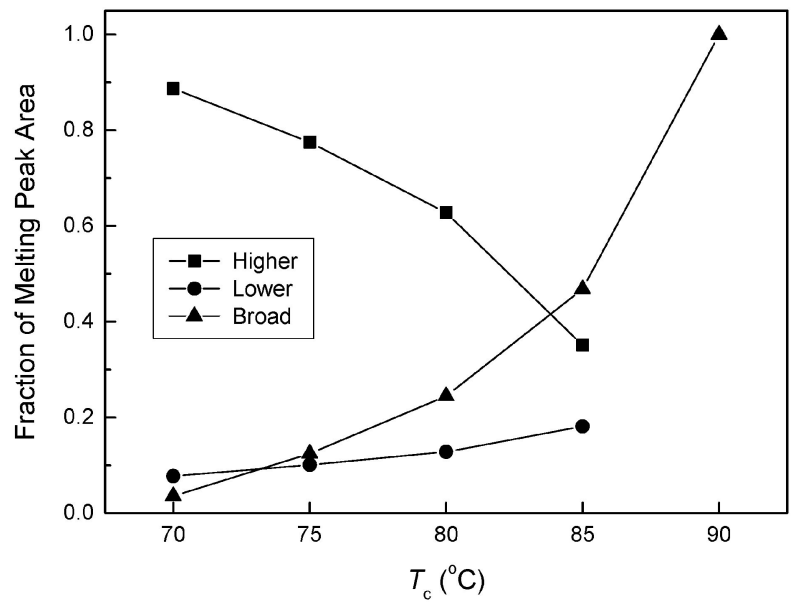

Figure 7. Relationships between the fraction of the peak area and $T_{\mathrm{c}}$ for each separated melting peak.

での急冷過程で結晶化する，高い融点をもつ分岐成分を ほとんど含まない結晶ドメイン；(ii) 等温結晶化過程で 結晶化する, 融点が $T_{\mathrm{c}}$ に依存する分岐成分を含む結晶 ドメイン；(iii) 等温結晶化後の急冷過程で結晶化する, ブロードな融解ピークをもつPE-PS 界面により近い PE 分子鎖からなる結晶ドメイン。これらの結晶ドメインの

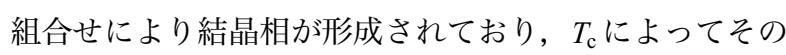
割合が異なることがわかった。ここで, $T_{\mathrm{c}}=90^{\circ} \mathrm{C}$ では単 一融解ピーク(ピーク形状からブロードピークとして率 属)が観察された。これは,このT榑では溶融状態に近い ため等温結晶化が進行せず，冷却過程でこれら三つの結 晶化メカニズムが段階的に起こるのではなく同時進行す るため, 拘束状態や分岐成分の存在状態に関係なく $\mathrm{PE}$ 分子鎖の結晶化が進行したと考えられる.そのため, 三 つの融解成分への分化が不十分となり, ブロードな単一 融解ピークを与えたと考元られる。このような結晶化の 進行は, 透過型電子顕微鏡 (TEM) を用いたモルフォロ ジー観察の結果からも示唆される ${ }^{19)} . T_{\mathrm{c}}$ の上昇ととも に結晶相の連続性が向上し, $T_{\mathrm{c}}=90^{\circ} \mathrm{C}$ であっても, 結晶 化時間を 24 時間まで長くすることで, 結晶相が連続し た共連続構造が観察された。系全体の分子運動性が高く なるPSの $T_{\mathrm{g}}$ に近い $T_{\mathrm{c}}$ での長時間での等温結晶化によ り，結晶相が連続した共連続構造が形成されたと考えら れる.

本研究では, PE- $b$-PS 等温結晶化試料で観察される DSC 融解ピークをピーク分離しその挙動を解析するこ とで, 共連続構造における結晶相中の結晶ドメイン形成 を評価することができた。本手法は，相分離構造がもた らす系内の分子鎖運動性の階層化あるいはブロック接合 点における分子鎖の拘束がその結晶化に複雑な影響を与 える結晶性ブロック共重合体の結晶化挙動の解析におい 
て非常に有用であると言える。

\section{4 結 論}

異なる $T_{\mathrm{c}}$ で等温結晶化させた PE- $b$-PS の DSC 融解挙 動をピーク分離法を用いて解析することで, その結晶化 挙動を調査した。メインピークは二重融解ピークを示 し， $T_{\mathrm{c}}$ にほとんど依存しない高温ピークと $T_{\mathrm{c}}$ に依存す る低温ピークが観察された。さらに，より低温側にブ ロードな融解ピークが観察された。得られた DSC 融解 曲線に対してピーク分離を行いそれぞれの挙動を解析し たところ，高温ピークは溶融状態から $T_{\mathrm{c}}$ までの急冷過 程で結晶化した分岐成分をほとんど含まない結晶の融 解，低温ピークは等温結晶化過程で結晶化した分岐成分 を含む結晶の融解に由来すると考えられた。また，ブ ロードピークはPE-PS 界面により近い PE 分子鎖からな る結晶の融解によるものと考えられた。これらの結果か ら, PE- $b$-PS 等温結晶化試料の結晶相は結晶化挙動の異 なる三つの結晶ドメイン；(i) 高い融点をもつ，分岐成 分をほとんど含まない結晶ドメイン；(ii) 融点が $T_{\mathrm{c}}$ に依 存する，分岐成分を含む結晶ドメイン；(iii) PE-PS界面 により近い $\mathrm{PE}$ 分子鎖からなる結晶ドメイン，からなる ことがわかった。このように DSC 融解曲線のピーク分 離により PE- $b$-PS 等温結晶化試料の融解挙動を解析する ことで，結晶相におけるドメイン形成を予想することが できた。この手法は，結晶性ブロック共重合体における 結晶化挙動の解析において非常に有用であると言える.

\section{文献}

1) E. Woo, J. Huh, Y. G. Jeong, and K. Shin, Phys. Rev. Lett., 98, 136103 (2007).

2) K. Shin, E. Woo, Y. G. Jeong, C. Kim, J. Huh, and K.-W. Kim, Macromolecules, 40, 6617 (2007).

3) H. Uehara, M. Ishizuka, H. Tanaka, M. Kano, and T. Yamanobe, RSC Adv., 6, 13971 (2016).

4) S. Nojima, M. Toei, S. Hara, S. Tanimoto, and S. Sasaki, Polymer, 43, 4087 (2002).

5) H. Takeshita, N. Ishii, C. Araki, M. Miya, K. Takenaka, and T. Shiomi, J. Polym. Sci., Part B: Polym. Phys., 42, 4199 (2004).

6) A. J. Müller, A. T. Lorenzo, M. L. Arnal, A. Boschetti de Fierro, and V. Abetz, Macromol. Symp., 240, 114 (2006).

7) A. T. Lorenzo, M. L. Arnal, A. J. Müller, A. Boschetti de Fierro, and V. Abetz, Macromolecules, 40, 5023 (2007).

8) H. Takeshita, Y.-J. Gao, T. Natsui, E. Rodriguez, M. Miya, K. Takenaka, and T. Shiomi, Polymer, 48, 7660 (2007).

9) R. V. Castillo, A. J. Müller, M.-C. Lin, H.-L. Chen, U.-S. Jeng, and M. A. Hillmyer, Macromolecules, 41, 6154 (2008).
10) T.-M. Chung, T.-C. Wang, R.-M. Ho, Y.-S. Sun, and B.-T. Ko, Macromolecules, 43, 6237 (2010).

11) T. Higa, H. Nagakura, T. Sakurai, and S. Nojima, Polymer, 51, 5576 (2010).

12) H. Uehara, Y. Karaki, S. Wada, and T. Yamanobe, ACS Appl. Mater. Interfaces, 2, 2707 (2010).

13) A. J. Müller and M. L. Arnal, Prog. Polym. Sci., 30, 559 (2005).

14) A. T. Lorenzo, M. L. Arnal, A. J. Müller, A Boschetti de Fierro, and V. Abetz, Eur. Polym. J., 42, 516 (2006).

15) S. Nojima, Y. Akutsu, A. Washino, and S. Tanimoto, Polymer, 45, 7317 (2004).

16) R. Hijikawa, L. Huang, G. Kiyofuji, H. Marubayashi, and S. Nojima, Polymer, 55, 6960 (2014).

17) S. Osawa, R. Hijikawa, H. Marubayashi, and S. Nojima, Polymer, 122, 249 (2017)

18) H. Uehara, T. Yoshida, M. Kakiage, T. Yamanobe, and $T$. Komoto, J. Polym. Sci., Part B: Polym. Phys., 44, 1731 (2006)

19) H. Uehara, T. Yoshida, M. Kakiage, T. Yamanobe, T. Komoto, K. Nomura, K. Nakajima, and M. Matsuda, Macromolecules, 39, 3971 (2006)

20) H. Uehara, M. Kakiage, M. Sekiya, D. Sakuma, T. Yamonobe, N. Takano, A. Barraud, E. Meurville, and P. Ryser, ACS Nano, 3, 924 (2009).

21) H. Uehara, M. Kakiage, M. Sekiya, T. Yamagishi, T. Yamanobe, K. Nakajima, T. Watanabe, K. Nomura, K. Hase, and M. Matsuda, Macromolecules, 42, 7627 (2009).

22) M. Kakiage, M. Sekiya, T. Yamanobe, and H. Uehara, Polymer, 52, 6146 (2011).

23) H. Uehara, M. Kano, H. Tanaka, S. Kato, H. Masunaga, and T. Yamanobe, RSC Adv, 4, 42467 (2014).

24) H. Uehara, M. Kakiage, H. Tanaka, and T. Yamonobe, Key Eng. Mater, 596, 50 (2014).

25) C. Vandermiers, J.-F. Moulin, P. Damman, and M. Dosière, Polymer, 41, 2915 (2000)

26) F. M. Mirabella, J. Polym. Sci., Part B: Polym. Phys., 39, 2800 (2001)

27) M. Nakae, H. Uehara, T. Kanamoto, A. E. Zachariades, and R. S. Porter, Macromolecules, 33, 2632 (2000).

28) Y. Yamamoto, Y. Inoue, T. Onai, C. Doshu, H. Takahashi, and H. Uehara, Macromolecules, 40, 2745 (2007).

29) 上原宏樹, 増田綾子, 山延 健, 分析化学, 67, 145 (2018).

30) B. Wunderlich and C. M. Cormier, J. Polym. Sci. Part A-2, 5, 987 (1967).

31) A. J. Müller, Z. H. Hernández, M. L. Arnal, and J. J. Sánchez, Polym. Bull., 39, 465 (1997).

32) X. Chen, J. Shi, L. Wang, H. Shi, Y. Liu, and L. Wang, Polym. Compos., 32, 177 (2011).

33) R. G. Alamo, E. K. M. Chan, L. Mandelkern, and I. G. VoigtMartin, Macromolecules, 25, 6381 (1992). 


\section{[Original Papers]}

Isothermal Crystallization Behavior of Polyethylene/Polystyrene Block Copolymer Estimated by Deconvolution Analysis of Differential Scanning Calorimetry Profiles

Masaki Kakiage*1, Miho Sekiya ${ }^{* 2}$, Daiki Tomiya ${ }^{* 2}$, Takeshi Yamanobe*2, and Hiroki Uehara*2

*1 Institute for Fiber Engineering, Shinshu University (IFES), Interdisciplinary Cluster for Cutting Edge Research (ICCER), Shinshu University (3-151 Tokida, Ueda 386-8567, Japan)

*2Division of Molecular Science, Faculty of Science and Technology, Gunma University (1-5-1 Tenjin-cho, Kiryu 376-8515, Japan)

An isothermally crystallized polyethylene/polystyrene diblock copolymer (PE- $b$-PS) film exhibited a characteristic melting behavior. In this study, the melting behavior of PE- $b$-PS isothermally crystallized at different crystallization temperatures $\left(T_{\mathrm{c}}\right)$ was investigated. Differential scanning calorimetry (DSC) melting thermograms for PE- $b$-PS isothermally crystallized at different $T_{\mathrm{c}} \mathrm{s}$ were measured, and a deconvolution analysis was performed. The higher-temperature melting peak, of which the temperature was independent of $T_{\mathrm{c}}$, was attributed to crystals formed during quenching from the molten state to $T_{\mathrm{c}}$. The lower-temperature melting peak, of which the temperature was dependent on $T_{\mathrm{c}}$, was attributed to crystals formed at $T_{\mathrm{c}}$. The broad melting peak observed at lower temperatures was attributed to crystals formed during quenching after the isothermal crystallization process. These results indicated that the deconvolution analysis of DSC profiles is useful for evaluating the constitution of crystalline domains in the bicontinuous crystalline/amorphous structure of isothermally crystallized PE- $b$-PS.

KEY WORDS Polyethylene/Polystyrene Block Copolymer / Isothermal Crystallization / Melting / DSC Measurement / Deconvolution

$$
\text { Analysis / }
$$

(Received September 6, 2018: Accepted November 5, 2018: Advance Publication December 18, 2018) (2019)]

[Kobunshi Ronbunshu, 76, 150-156

(C)2019, The Society of Polymer Science, Japan 